УДК 338.48-6:63:334.72-053.81

DOI https://doi.org/10.32851/2708-0366/2020.4.13

\author{
Крикунова В.М. \\ кандидат економічних наук, \\ доцент кафедри готельно-ресторанного \\ та туристичного бізнесу й іноземних мов, \\ Херсонський державний аграрно-економічний університет \\ ORCID: https://orcid.org/0000-0001-5710-8029 \\ Алєщенко Л.О. \\ асистент кафедри менеджменту \\ та інорормаційних технологій, \\ Херсонський державний аграрно-економічний університет \\ ORCID: https://orcid.org/0000-0002-7119-2922
}

Krykunova Viktoriia, Aleshchenko Liudmila Kherson State Agrarian and Economic University

\title{
СТРАТЕГІЧНІ ПРІОРИТЕТИ РОЗВИТКУ МОЛОДІЖНОГО ПІДПРИЄМНИЦТВА ХЕРСОНСЬКОЇ ОБЛАСТІ У СФЕРІ ТУРИСТИЧНОГО БІЗНЕСУ
}

\section{THE STRATEGIC PRIORITIES OF THE YOUTH ENTREPRENEURSHIP DEVELOPMENT IN THE FIELD OF TOURISM BUSINESS IN KHERSON REGION}

\begin{abstract}
Мета статті полягає у визначенні пріоритетів розвитку туристичного молодіжного підприємництва в Херсонській області та його ролі в реалізації туристичного потенціалу регіону. Використано абстрактно-логічний метод (обгрунтування теоретичних положень, систематизація чинників розвитку), статистичного аналізу (характеристика стану аналізованого сектору підприємництва). Потенціал молодіжного підприємництва динамічна і креативна реакція на виклики зовнішнього середовища, реалізачія бізнес-ідеі соиіально відповідально, схильність до інновачійного інвестування. Його активація у туристичному бізнесі передбачає створення умов для промоиії, диверсифікаџї та підвищення якості туристичних продуктів, стимулювання крафтових виробництв, таргетовану державну фінансову, правову та інформаційну підтримку.
\end{abstract}

Ключові слова: молодіжне підприємництво, індустрія туризму, туристичне молодіжне підприсмництво, туристична дестинація, туристично-рекреаційний потениіал.

Цель статьи заключается в определении приоритетов развития туристического молодежного предпринимательства в Херсонской области и его роли в реализации туристического потеничиала региона. Использовань абстрактно-логический метод (обоснование теоретических положений, систематизация факторов развития), статистического анализа (характеристика состояния рассматриваемого сектора предпринимательства). Потенциал молодежного предпринимательства - динамичная и креативная реакиия на вызовы внешней среды, реализация бизнес-идеи социально ответственно, склонность к инновационному инвестированию. Его активация в туристическом бизнесе предусматривает создание условий для продвижения, диверсификации и повылиения качества туристических продуктов, стимулирование крафтовых производств, таргетированную государственную финансовую, правовую и информационную поддержку.

Ключевые слова: молодежное предпринимательство, индустрия туризма, туристическое молодежное предпринимательство, туристическая дестинация, туристско-рекреационный потенцииал.

The purpose of the article is to identify the strategic priorities of tourism youth entrepreneurship development in Kherson region and its role in realizing the tourism potential of the region. On this basis, the following tasks are formed: to conduct an economic assessment of tourism businesses, 
to determine the vectors of development of the youth entrepreneurship in tourism industry and to substantiate the prospects of effective social partnership in this field. Entrepreneurship is the ecosystem of modern thriving economy. It is the engine for economic development, effective employment, unemployment decrease, the quality of life improvement. Developed countries experience shows that in the business sector structure, small and medium-sized businesses play a key role for the employment and economic growth ensuring. Small and medium business is the very sector where the business activity of young people, the most dynamic, flexible, prone to risk, and at the same time - one of the most vulnerable group of the population, is mainly realized. Youth entrepreneurship performs important social and economic functions, including the creation of new jobs, unemployment decrease, the formation of practical knowledge and business skills, soft skills, foundation for self-actualization and self-development, etc. Expanding prospects and activating the youth entrepreneurship development creates prerequisites of its potential use in traditional and new areas, where it is necessary to upgrade dynamically, to respond to the external environment challenges creatively, to implement business ideas socially responsibly, to consider investment objects from an unexpected angle. One of such objects today is tourism and hospitality industry, the development of which is undergoing structural transformations due to the pandemic, but remains a trend in the modern economy and has the potential for broad prospects for entrepreneurial activity of young people. To achieve this goal, the problems and prospects of youth business in the tourism sector are studied and proposals for its further effective development are provided. The methods of abstract and logical reasoning of theoretical positions on a theme are applied, statistical research of this sector of business development, systematization of the factors defining the branch performance are used. The article examines the formation and practical use of competitive advantages of youth entrepreneurship in the tourism business. The necessity of development and popularization of this type of business among the population of Ukraine is substantiated. Qualitative components of competitive advantages that form the tourist image of the region are analyzed. The components and directions of providing competitive advantages in the tourism sector at the regional level, the need to increase its investment attractiveness, financial recovery, government support and legal regulation are considered. The measures proposed for the development and implementation of competitive advantages can be used to justify the regional programs of tourism youth entrepreneurship development.

Key words: youth entrepreneurship, tourism industry, tourism youth entrepreneurship, tourism destination, tourism and recreational potential.

Постановка проблеми. Підприємницька діяльність становить основу сучасної економіки, формує умови для ефективного економічного розвитку, спрямованого на задоволення різноманітних потреб суспільства та підвищення якості життя. Досвід розвинутих країн показує, що у структурі підприємництва суб'єкти малого і середнього бізнесу відіграють визначальну роль у забезпеченні зайнятості населення, формуванні середнього класу і ВВП, стимулюванні економічного зростання. Саме у сфері МСБ переважно розпочинається та реалізується підприємницька активність молоді. Концептуально філософія малого і середнього бізнесу: гнучкість, адаптивність, новаторські управлінські підходи відповідає запитам і характеристикам молодих людей, які здатні динамічно розвиватися, креативно реагувати на виклики зовнішнього середовища, реалізувати бізнес-ідеї соціально відповідально, розглядати традиційні й нові сфери інвестування під неочікуваним кутом зору тощо [1]. Однією з таких сфер сьогодні є індустрія туризму та гостинності, розвиток якої зазнає структурних трансформацій унаслідок впливу пандемії, проте залишається трендом сучасної економіки й має потенціал для реалізації підприємницької активності молоді.

Реалізація поставлених стратегічних завдань у туристичній галузі України можлива на основі визначення стратегічних пріоритетів розвитку та напрямів стимулювання молодіжного бізнесу у сферу туризму, ефективної співпраці суб'єктів туризму та органів влади з урахуванням регіональних конкурентних переваг і наявного потенціалу. Цим зумовлена актуальність вибраної теми публікації.

Аналіз останніх досліджень і публікацій. Концептуальні та прикладні питання молодіжного підприємництва проаналізовано у працях Ю. Кирилова, Г. Жосан [2], I. Жданова [3], О. Дідуха [4], О. Мельниченка [5], Н. Корпач [6]. Соціально-економічні 
аспекти розвитку індустрії туризму розглядають В. Грановська, Ю. Кирилов [7; 8], С. Васильчак, С. Семак [9], С. Газуда [10], С. Грабовенська [11].

Формулювання цілей статті. Метою статті $є$ визначення стратегічних пріоритетів розвитку молодіжного підприємництва в секторі туризму Херсонської області та розроблення пропозицій щодо реалізації туристичного потенціалу регіону. На цій основі поставлено завдання провести економічну оцінку діяльності суб'єктів туристичного бізнесу, визначити вектори молодіжного підприємництва в індустрії туризму та обгрунтувати перспективи ефективного соціального партнерства у цій сфері.

Виклад основного матеріалу. Досліджувана тематика має теоретичне та стратегічне прикладне значення на національному та регіональному рівнях, що відображено у відповідних програмних розробках. У Стратегії розвитку туризму та курортів на період до 2026 р. зазначено, що для раціонального й ефективного використання туристичних, природних, лікувальних та рекреаційних ресурсів України необхідно сформувати туристично-рекреаційний простір шляхом створення та забезпечення функціонування зон розвитку туризму та курортів і розробити, впровадити та запропонувати споживачеві конкурентоспроможний національний туристичний продукт [12].

У Стратегії розвитку Херсонської області на період 2021-2027 рр. у реалізації стратегічної мети «Місцевий економічний розвиток з урахуванням діджиталізації та інноваційно-інвестиційних процесів» об'єктом операційної цілі виступає сфера туристичного бізнесу: «Туристично-рекреаційна індустрія для оздоровлення, відпочинку та інтелектуально-духовного збагачення людей». У зв'язку із цим передбачено пріоритет збалансованого розвитку рекреаційних можливостей Херсонської області - регіонів Азовського, а також Чорноморського узбережжя. Також через активізацію зеленого туризму відбуватиметься розширення надання послуг на території Нижньодніпровського національного парку. Функціонування туристичної сфери враховуватиме гранично допустимий рівень антропогенного навантаження на територію. Розвиток індустрії гостинності і туризму, управління туристичними дестинаціями грунтуватиметься на комплексному маркетинговому підході до культурно-історичного та рекреаційного потенціалу області та спрямовуватиметься на нарощування потенціалу туристичних ресурсів.

Мета може бути досягнута шляхом подовження туристичного сезону в рекреаційних зонах, поліпшення якості туристичних послуг через упровадження сертифікації послуг на основі міжнародних стандартів, діджиталізацію інформаційного забезпечення та обслуговування, розвиток нових туристичних дестинацій і продуктів, створення умов для промоції туристичного продукту.

Важливим складником буде забезпечення доступності туристичних об'єктів завдяки запровадженню мультимовної системи ознакування та навігації на Херсонщині, ознакуванню та маркуванню маршрутів активного туризму, впорядкуванню знакових пам'яток історії та культури Степового Причорномор'я, забезпеченню їх інфраструктурою для відвідування туристами.

Очікувані результати реалізації завдання:

- створення мережі інформаційної підтримки туристичної галузі;

- упровадження системи стандартизації закладів розміщення;

- проведення ознакування туристичних маршрутів;

- подовження туристичного сезону від травня до жовтня;

- удосконалення бази підготовки кадрів для розвитку туристичної галузі, а саме для активного залучення молоді, що забезпечить мультивекторний розвиток аналізованої індустрії [13].

Переваги Херсонської області як території для формування та розвитку туристично-територіального комплексу та молодіжного бізнесу в ньому зумовлені системою природних чинників (табл. 1). 
Таблиця 1

Можливості зовнішнього середовища

функціонування туристично-територіального комплексу Херсонської області для розвитку молодіжного підприсмництва

\begin{tabular}{|c|c|}
\hline Групи чинників & Наявні об'скти \\
\hline \multirow{8}{*}{$\begin{array}{l}\text { Природно- } \\
\text { кліматичні }\end{array}$} & $\begin{array}{l}\text { - унікальні кліматичні умови, привабливі для туристів із північних і } \\
\text { західних регіонів; }\end{array}$ \\
\hline & - значна тривалість безморозного періоду; \\
\hline & $\begin{array}{l}\text { - можливість розвитку гастрономічного туризму на основі автентичних, } \\
\text { локальних та унікальних продуктів; }\end{array}$ \\
\hline & - доступ до Дніпровської водної магістралі; \\
\hline & - вихід одночасно до двох морів - Чорного і Азовського; \\
\hline & - єдина в Європі природна пустеля Олешківські піски; \\
\hline & - найбільший у Європі рукотворний ліс; \\
\hline & - унікальні горні ландшафти «Станіславські кручі» \\
\hline \multirow{7}{*}{$\begin{array}{l}\text { Курортно- } \\
\text { рекреаційні }\end{array}$} & -12 курортних населених пунктів; \\
\hline & $\begin{array}{l}\text { - понад } 450 \text { км морської берегової лінії, з них } 200 \text { км обладнаних } \\
\text { піщаних пляжів; }\end{array}$ \\
\hline & - найдовша піщана коса у світі Арабатська стрілка; \\
\hline & $\begin{array}{l}\text { - понад } 70 \text { родовищ цілющих бальнеологічних ресурсів (мінеральних } \\
\text { і термальних вод, лікувальних грязей, ропи соляних озер, зокрема } \\
\text { сертифіковані продукти Лемурійського озера); }\end{array}$ \\
\hline & $\begin{array}{l}\text { - місто Скадовськ - курорт державного значення, центр дитячого } \\
\text { оздоровлення та відпочинку; }\end{array}$ \\
\hline & $\begin{array}{l}\text { - понад } 1000 \text { об’єктів відпочинку, оздоровлення та розміщення, } \\
3 \text { них } 49 \text { дитячих, } 60 \text { садиб зеленого туризму, } 51 \text { готельний комплекс; }\end{array}$ \\
\hline & - загальний ліжковий фонд понад 100 тис місць \\
\hline \multirow{2}{*}{$\begin{array}{l}\text { Природно- } \\
\text { заповідний фонд } \\
\text { національного, } \\
\text { міжнародного } \\
\text { та місцевого } \\
\text { значення }\end{array}$} & $\begin{array}{l}\text { - біосферні заповідники - Чорноморський та Асканія-Нова, } \\
\text { що охороняються ЮНЕСКО; }\end{array}$ \\
\hline & $\begin{array}{l}\text { - національні природні парки: «Азово-Сиваський», «Олешківські піски», } \\
\text { «Джарилгацький», «Нижньодніпровський», «Кам’янська Січ» }\end{array}$ \\
\hline
\end{tabular}

Сьогодні для надання туристичних послуг розроблено понад 90 маршрутів на території Херсонщини різного спрямування та для різних вікових категорій, найпопулярнішими 3 яких є: науково-пізнавальні маршрути по біосферному заповіднику Асканія-Нова, пішохідні маршрути по одній із найбільших піщаних пустель Свропи «Олешківські піски», відвідування пам'ятника історії українського козацтва національного значення - Кам'янської Січі, по об'єктах історико-культурної спадщини обласного центру та інших історичних місцях.

Також в області активно розвивається водний туризм, сільський зелений, винний, екологічний, історико-культурний, гастрономічний, подієвий. Туристичні пропозиції задовольняють попит на атмосферні тури на будь-який смак та для будь-якої вікової категорії і в будь-яку пору року: кайтінг, яхтинг, байдарки, прогулянки на квадроциклах, риболовля, полювання, театр під відкритим небом, відвідування Долини тюльпанів, подорожування козацькими шляхами та багато інших туристичних атракцій. 
Активні види туризму є особливо перспективними для розвитку молодіжного підприємництва.

Туризм, відпочинок, лікування та оздоровлення набувають усе відчутнішого значення у соціально-економічному розвитку Херсонщини. Але значна частина природних територій, об’єктів культурної спадщини та туристичної інфраструктури непристосована відповідно до міжнародних вимог для туристичних відвідувань, а туристичні послуги в усіх секторах індустрії туризму здебільшого не відповідають вимогам до якості обслуговування [14].

Зазначені проблемні аспекти позначалися на динаміці та структурі туристичних потоків. Відповідно до офіційних даних, у період 2015-2019 рр. сукупний туристичний потік характеризується виразно позитивною динамікою (табл. 2). Разом із тим зростання зумовлено виключно стабільним збільшенням кількості виїзних туристів, що свідчить про зниження уваги до локальних туристичних продуктів, а також негативний вплив вищеозначених чинників.

Таблиця 2

Динаміка кількості туристів, обслуговуваних туроператорами та турагентами, у Херсонській області [15]

\begin{tabular}{|c|c|c|c|c|c|c|c|c|c|}
\hline \multirow{3}{*}{ Роки } & \multicolumn{9}{|c|}{ Туристичні потоки } \\
\hline & \multicolumn{2}{|c|}{$\begin{array}{l}\text { Кількість } \\
\text { туристів, }\end{array}$} & \multicolumn{2}{|c|}{$\begin{array}{c}\text { В'їзні } \\
\text { (іноземні) } \\
\text { туристи }\end{array}$} & \multicolumn{2}{|c|}{ Виїзні туристи } & \multicolumn{3}{|c|}{ Внутрішні туристи } \\
\hline & $\begin{array}{c}\text { всього, } \\
\text { осіб }\end{array}$ & $\begin{array}{c}\text { темп } \\
\text { росту, } \\
\%\end{array}$ & осіб́ & $\begin{array}{c}\text { темп } \\
\text { росту, } \\
\%\end{array}$ & осіб & $\begin{array}{c}\text { темп } \\
\text { росту, } \\
\%\end{array}$ & осіб & $\begin{array}{c}\text { темп } \\
\text { росту, } \\
\%\end{array}$ & $\begin{array}{l}\text { \% до зага- } \\
\text { льної } \\
\text { кількості }\end{array}$ \\
\hline 2000 & 61275 & - & 5929 & - & 1116 & - & 54230 & - & - \\
\hline 2001 & 64312 & 105,0 & 7858 & 132,5 & 2021 & 181,1 & 54433 & 100,4 & 84,6 \\
\hline 2002 & 94607 & 147,1 & 5165 & 65,7 & 2728 & 135,0 & 86714 & 159,3 & 91,7 \\
\hline 2003 & 107351 & 113,5 & 7149 & 138,4 & 4216 & 154,5 & 95986 & 110,7 & 89,4 \\
\hline 2004 & 63361 & 59,0 & 5179 & 72,4 & 4098 & 97,2 & 54084 & 56,3 & 85,4 \\
\hline 2005 & 70183 & 110,8 & 4979 & 96,1 & 5273 & 128,7 & 59931 & 110,8 & 85,4 \\
\hline 2006 & 69203 & 98,6 & 7133 & 143,3 & 5084 & 96,4 & 56986 & 95,1 & 82,3 \\
\hline 2007 & 71054 & 102,7 & 7785 & 109,1 & 5574 & 109,6 & 57695 & 101,2 & 81,2 \\
\hline 2008 & 94200 & 132,6 & 6412 & 82,4 & 6694 & 120,1 & 81094 & 140,6 & 86,1 \\
\hline 2009 & 128096 & 136,0 & 4356 & 67,9 & 6284 & 93,9 & 11745 & 14,5 & 9,2 \\
\hline 2010 & 94156 & 73,5 & 3494 & 80,2 & 6046 & 96,2 & 84616 & 720,4 & 89,9 \\
\hline 2011 & 37672 & 40,0 & 1623 & 46,5 & 3696 & 61,1 & 32353 & 38,2 & 85,9 \\
\hline 2012 & 17494 & 46,4 & 35 & 2,2 & 6512 & 176,2 & 10947 & 33,8 & 62,6 \\
\hline 2013 & 16122 & 92,2 & 5 & 14,3 & 7863 & 120,7 & 8254 & 75,4 & 51,2 \\
\hline 2014 & 15818 & 98,1 & 1 & 20,0 & 8332 & 106,0 & 7485 & 90,7 & 47,3 \\
\hline 2015 & 11720 & 74,1 & - & - & 7234 & 86,8 & 4486 & 59,9 & 38,3 \\
\hline 2016 & 16584 & 141,5 & - & - & 10090 & 139,5 & 6494 & 144,8 & 39,2 \\
\hline 2017 & 20278 & 122,3 & - & - & 14747 & 146,2 & 5531 & 85,2 & 27,3 \\
\hline 2018 & 26130 & 128,9 & - & - & 19702 & 133,6 & 6428 & 116,2 & 24,6 \\
\hline 2019 & 28113 & 107,6 & 7 & - & 23607 & 119,8 & 4499 & 70,0 & 16,0 \\
\hline
\end{tabular}


Наведені офіційні дані також не враховують осіб, які самостійно організовують свої поїздки, безпосередньо звертаючись до закладів розміщення та інших інфраструктурних об'єктів.

У 2020 р. на стан індустрії гостинності і туризму суттєво вплинула пандемія, зумовивши скорочення туристичних потоків, кількості туристичних агентів (станом на червень 2020 р. закрито понад 7 тис турагенцій по всій країні), зниження платоспроможного попиту, загального обсягу послуг, податкових надходжень, утрату кадрового потенціалу через вимушене закриття тощо. У глобальному вимірі через пандемію коронавірусу потік туристів скоротився на 65\% (за даними Всесвітньої туристичної організації ОOH (UNWTO)). Падіння попиту на міжнародні поїздки за період із січня по червень 2020 р. призвело до скасування 440 млн міжнародних поїздок та втрати близько 460 млрд дол. США, що приблизно вп’ятеро більше, ніж збитки, завдані туристичному бізнесу в 2009 р. через глобальну економічну кризу. За оцінками UNWTO, на повернення індустрії до рівня туристичного потоку 2019 р. потрібно від двох до чотирьох років [16].

Водночас економічні агенти досліджуваної сфери всередині країни активно започатковують нові туристичні продукти та послуги, урізноманітнюють та кастомізують їх, наприклад розробляють тури вихідного дня різного змісту, короткострокові подорожі, що позитивно впливатиме на стан внутрішнього туризму.

Надання туристичних послуг у Херсонській області забезпечують 14 туроператорів, понад 100 туристичних агентів та близько 60 екскурсоводів, які обслуговують відвідувачів музеїв, заповідників, культурно-історичних комплексів. Проведений аналіз продемонстрував, що цього недостатньо для активного розвитку туризму, тому цей напрям може стати пріоритетним для розвитку молодіжного підприємництва.

3 одного боку, індустрія туризму і гостинності потребує пом'якшення соціальноекономічних наслідків кризи на глобальному рівні, спрямованого на економічне виживання суб'єктів туристичного бізнесу, основними передумовами якого є підвищення стійкості ланцюга вартості у сфері туризму, максимальне використання сучасних технологій, зокрема «зеленого» зростання, а також зміцнення партнерських зв'язків для сталого розвитку. 3 іншого боку, у цілому експерти оцінюють позитивно перспективи внутрішнього туризму в Україні, зокрема туристи віддаватимуть перевагу індивідуальному, родинному відпочинку на природі, екотуризму, короткостроковим тематичним турам.

Для відновлення позитивної динаміки та розвитку туристичного молодіжного бізнесу на регіональному рівні необхідна одночасна скоординована реалізація заходів на рівні економічних агентів та владних структур:

1. Створення умов для промоції туристичного продукту:

- поліпшення ринкової і транспортної інфраструктури;

- створення мережі регіональних туристично-інформаційних центрів;

- сприяння впровадженню державних, міжнародних стандартів у туристичній cфepi;

- промоція туристичного бренду Херсонської області.

2. Поліпшення якості туристичних послуг:

- підвищення якості підготовки фахівців у галузі гостинності;

- упровадження сучасних технологій маркетингу і брендування туристичного продукту;

- застосування системи менеджменту якості, міжнародних стандартів у туристичній сфері;

- сприяння розробленню та запровадженню мультимовної системи ознакування та навігації на Херсонщині;

- сприяння ознакуванню та маркуванню маршрутів активного туризму; 
- впорядкування знакових пам'яток історії та культури Степового Причорномор'я, забезпечивши їх інфраструктурою для відвідування туристів;

- діджиталізація інформаційної підтримки та обслуговування;

- забезпечення організаційної, інформаційної та промоційної підтримки наявних фестивалів та івент-заходів, що проходять не в літній період.

3. Створення умов для розвитку внутрішнього рекреаційного туризму:

- інфраструктурне забезпечення рекреаційних територій області;

- формування та просування кейсів туристичних пропозицій (магніти), орієнтованих на внутрішнього туриста (кластери «Соляна дорога», «Таврійське екооздоровлення», проект Tavria SPA Resort), екологічні стежки Херсонщини.

4. Підтримка крафтових виробництв та розвитку еногастрономічного туризму:

- упровадження проєктів із виробництва крафтової автентичної локальної продукції (сири, бринза, в'ялене та сушене плодоовочівництво, маринади, джеми, вино, снеки фруктові та овочеві, тютюн, спеції, устриці, равлики, цвіркуни тощо);

- оздоровче харчування на основі насіння олійних культур;

- створення агротуристичної карти області;

- реалізація стимулів до вирощування екологічно чистої продукції, впровадження органічного землеробства.

5. Таргетоване сприяння розвитку туристичного молодіжного підприємництва:

- фінансова підтримка суб'єктів молодіжного бізнесу шляхом компенсації відшкодування відсоткових ставок за кредитами, у кризових умовах - відтермінування відповідальності за зобов'язаннями, звільнення від податків на землю, нерухомість;

- навчання у сфері туристичного підприємництва (тренінги з місцевого туристичного потенціалу, аналізу профілю туристів, міжкультурного діалогу, нетворкінгу, маркетингу і брендингу для туристичного бізнесу, електронної торгівлі та цифрових платформ, стратегій ціноутворення, місць розміщення, фінансового забезпечення);

- популяризація соціально відповідального бізнесу (провадження заходів щодо підвищення рівня дисципліни сплати податків; уведення ефективних інноваційних інструментів комунікації бізнесу та територіальних громад, що сприятиме зростанню рівня довіри та формування лояльності).

Висновки. Аналіз передумов та тенденцій розвитку молодіжного бізнесу у сфері туризму Херсонської області дає змогу стверджувати, що область має значні можливості, щоб увійти до найбільш розвинутих у туристичному відношенні регіонів: вигідне геополітичне розташування, комфортні кліматичні умови, різноманітний ландшафт, унікальну флору і фауну, історико-культурну, архітектурну спадщину, достатні людські, матеріальні, у тому числі природно-оздоровчі, ресурси. У розвитку індустрії туризму і гостинності особлива роль належить молодіжному підприємництву, що реалізує унікальні характеристики його економічних агентів: креативність, схильність до ризику, нестандартних рішень тощо. Бізнес-активність молоді має широкі перспективи реалізації на основі туристично-рекреаційного та історико-культурного потенціалу Херсонської області, особливо в тому, що стосується активних видів відпочинку, екотуризму, а також розвитку ринкової інфраструктури індустрії туризму та ії діджиталізації.

Водночас туристичне молодіжне підприємництво потребує реалізації системи заходів із боку суб'єктів виконавчої влади та місцевого самоврядування, залучення значних інвестицій у розбудову туристично-рекреаційної інфраструктури області та приведення ії у відповідність до міжнародних стандартів, фінансової підтримки через систему ринкових важелів (зниження відсоткової ставки або ії відшкодування, податкові пільги), популяризації трендових видів туризму (еногастротуризму, екстремального, екотуризму тощо). 


\section{Список використаних джерел:}

1. Жосан Г.В. Визначення стейкхолдерів молодіжного підприємництва. Integración de las ciencias fundamentales y aplicadas en el paradigma de la sociedad post-industrial : Colección de documentos científicos $\langle\Lambda \mathrm{O} \mathrm{O} \mathrm{O} \Sigma$ » con actas de la Conferencia Internacional Científica y Práctica (Vol. 1), 24 de abril de 2020. Barcelona, España : Plataforma Europea de la Ciencia. P. 48-52. URL: https://ojs.ukrlogos.in.ua/index.php/logos/issue/view/24.04.2020/280 (дата звернення: 02.11.2020).

2. Yurii Kyrylov, Natalia Kyrychenko, Tatyana Stukan and Hanna Zhosan, Formation of Enterprise. Management Strategies and Entrepreneurship Training, International Journal of Management. 2020. № 11(6). P. 793-800. URL: http://www.iaeme.com/MasterAdmin/Journal uploads/ijm/VOLUME_11_ISSUE_6/IJM_11_06_067.pdf (дата звернення: 02.11.2020).

3. Жданов І.О. Формування та реалізація державної молодіжної політики в Україні в умовах децентралізації. Тернопіль : Тернограф, 2017. С. 100.

4. Дідух О.О. Соціологічний аналіз проблеми безробіття серед української молоді. Грані. 2016. № 5. C. 68-75.

5. Мельниченко О. Молодіжний ринок праці України: проблеми і перспективи. Психологія і суспільство. 2015. № 3. С. 99-104.

6. Корпач Н. Основні напрями реалізації державної молодіжної політики в Україні: соціально-педагогічний аспект. Педагогічний часопис Волині. 2016. № 2. С. 30-34.

7. Yuriy Kyrylov, Viktoriia Hranovska, Hanna Zhosan, Inna Dotsenko, Innovative Development of Agrarian Enterprises of Ukraine in the Context of the Fourth Industrial Revolution. Solid State Technology. 2020. Vol. 63. Issue 6. P. 1430-1448. URL: http://solidstatetechnology.us/index.php/ JSST/article/view/2218 (дата звернення: 03.11.2020).

8. Кирилов Ю.С., Грановська В.Г., Алєщенко Л.О. Економічний механізм формування конкурентних переваг суб'єктів туристичної галузі. Економіка АПК. 2020. № 5. С. 45-55.

9. Васильчак С.В., Семак С.С. Формування конкурентоспроможності туристичних підприємств у контексті забезпечення економічної безпеки. Економічний вісник Донбасу. 2014. № 3 С. 61-64.

10. Газуда С.М. Конкурентні переваги регіонального розвитку сфери туризму. Миколаївський національний університет імені В.О. Сухомлинського. 2016. № 14. С. 106-110.

11. Грабовенська С.П. Конкурентоспроможність територіальних ринків туристичних послуг в Україні : дис. ... канд. екон. наук : 08.00 .03 ; Львівський національний університет імені Івана Франка. Львів, 2017. 222 с.

12. Про схвалення Стратегії розвитку туризму та курортів на період до 2026 року : Розпорядження Кабінету міністрів України № 168 від 16.03.2017. URL: https://zakon.rada.gov.ua/laws/ show/168-2017-\%D1\%80 (дата звернення: 03.10.2020).

13. Стратегія розвитку Херсонської області на період 2021-2027 років. URL: https://khoda.gov.ua/strateg\%D1\%96ja-rozvitku-2021-2027 (дата звернення: 07.04.2020).

14. Відпочинок і туризм у Херсонській області у 2019 році : статистичний бюлетень / Головне управління статистики у Херсонській області. Херсон, 2020. 54 с.

15. Кількість туристів, обслугованих туроператорами та турагентами, за видами туризму (2000-2019 рр.) / Головне управління статистики у Херсонській області. URL: http://www.ks.ukrstat.gov.ua/statistichna-informatsiya/728-turizm/2057-turistichni-potoki2000-2011-rr.html (дата звернення: 17.10.2020).

16. Пандемія COVID-19 та іï̈ наслідки у сфері туризму в Україні. URL: http://www.ntoukraine.org/ assets/files/EBRD-COVID19-Report-UKR.pdf (дата звернення: 17.11.2020).

\section{References:}

1. Zhosan G.V. (2020) Vyznachennia steikkholderiv molodizhnoho pidpryiemnytstva [Identification of youth entrepreneurship stakeholders]. Integración de las ciencias fundamentales y aplicadas

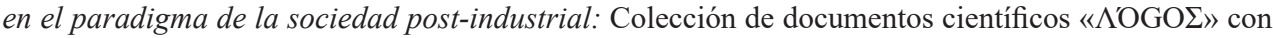
actas de la Conferencia Internacional Científica y Práctica (Vol. 1), 24 de abril de 2020. Barcelona, España: Plataforma Europea de la Ciencia. P. 48-52. Available at: https://ojs.ukrlogos.in.ua/index.php/ logos/issue/view/24.04.2020/280 (accessed 02 November 2020).

2. Yurii Kyrylov, Natalia Kyrychenko, Tatyana Stukan, Hanna Zhosan (2020) Formation of Enterprise. Management Strategies and Entrepreneurship Training, International Journal of Management, no. 11 (6), pp. 793-800. Available at: http://www.iaeme.com/MasterAdmin/Journal_uploads/ ijm/VOLUME_11_ISSUE_6/IJM_11_06_067.pdf (accessed 02 November 2020). 
3. Zhdanov I.O. (2017) Formuvannya ta realizaciya derzhavnoyi molodizhnoyi polityky v Ukrayini $\mathrm{v}$ umovah decentralizaciyi [Formation and implementation of state youth policy in Ukraine in the conditions of decentralization]. Ternopil: TOV «Ternograf». (in Ukrainian)

4. Didukh O.O. (2016) Sotsiolohichnyi analiz problemy bezrobittia sered ukrainskoi molodi [Sociological analysis of the problem of unemployment among Ukrainian youth]. Grani, no. 5, pp. 68-75.

5. Melnychenko O. (2015) Molodizhnyi rynok pratsi Ukrainy: problemy i perspektyvy [Youth labor market of Ukraine: problems and prospects]. Psykholohiia i suspilstvo, no. 3, pp. 99-104.

6. Korpach N. (2016) Osnovni napriamy realizatsii derzhavnoi molodizhnoi polityky v Ukraini: sotsialno-pedahohichnyi aspekt [The main directions of implementation of the state youth policy in Ukraine: social and pedagogical aspect]. Pedahohichnyi chasopys Volyni, no. 2, pp. 30-34.

7. Yuriy Kyrylov, Viktoriia Hranovska, Hanna Zhosan, Inna Dotsenko (2020) Innovative Development of Agrarian Enterprises of Ukraine in the Context of the Fourth Industrial Revolution. Solid State Technology, vol. 63, Issue 6, pp. 1430-1448 (accessed 03 November 2020).

8. Kyrylov Yu.Ye., Hranovska V.H., Alieshchenko L.O. (2020) Ekonomichnyi mekhanizm formuvannia konkurentnykh perevah subiektiv turystychnoi haluzi [Economic mechanism of formation of competitive advantages of subjects of tourist branch]. Ekonomika APK, no. 5, pp. 45.

9. Vasylchak S.V., Semak S.S. (2014) Formuvannia konkurentospromozhnosti turystychnykh pidpryiemstv u konteksti zabezpechennia ekonomichnoi bezpeky [Formation of competitiveness of tourist enterprises in the context of economic security]. Ekonomichnyi visnyk Donbasu, no. 3, pp. 61-64.

10. Hazuda S.M. (2016) Konkurentni perevahy rehionalnoho rozvytku sfery turyzmu [Competitive advantages of regional development of tourism]. Mykolaivskyi natsionalnyi universytet imeni V.O. Sukhomlynskoho, no. 14, pp. 106-110.

11. Hrabovenska S.P. (2017) Konkurentospromozhnist terytorialnykh rynkiv turystychnykh posluh v Ukraini [Competitiveness of territorial markets of tourist services in Ukraine] (PhD Thesis), Lviv: Lvivskyi natsionalnyi universytet imeni Ivana Franka.

12. Pro shvalennya Strategiyi rozvytku turyzmu ta kurortiv na period do 2026 roku [On approval of the Strategy for the development of tourism and resorts for the period up to 2026] Rozporyadzhennya Kabinetu ministriv Ukrayiny no. 168 vid 16.03.2017. Available at: https://zakon.rada.gov.ua/laws/ show/168-2017-\%D1\%80 (accessed 03 October 2020).

13. Stratehiia rozvytku Khersonskoi oblasti na period 2021-2027 rokiv [Development strategy of Kherson region for the period 2021-2027]. Available at: https://khoda.gov.ua/strateg\%D1\%96ja-rozvitku-2021-2027 (accessed 07 April 2020).

14. Vidpochynok i turyzm u Khersonskii oblasti u 2019 rotsi: statystychnyi biuleten [Recreation and tourism in the Kherson region in 2019: statistical bulletin]. Holovne upravlinnia statystyky u Khersonskii oblasti, 2020.

15. Kilkist turystiv, obsluhovanykh turoperatoramy ta turahentamy, za vydamy turyzmu (2000-2019) [Number of tourists served by tour operators and travel agents, by type of tourism (2000-2019)]. Holovne upravlinnia statystyky u Khersonskii oblasti. Available at: http://www.ks.ukrstat.gov.ua/statistichna-informatsiya/728-turizm/2057-turistichni-potoki-20002011-rr.html (accessed 17 October 2020).

16. Pandemiya COVID-19 ta yiyi naslidky` u sferi tury`zmu v Ukrayini [The COVID-19 pandemic and its consequences in the field of tourism in Ukraine]. Available at: http://www.ntoukraine.org/ assets/files/EBRD-COVID19-Report-UKR.pdf (accessed 17 November 2020). 